\title{
INOVASI PELAYANAN SIM BOOKING DI SATLANTAS POLRES KUDUS
}

\author{
Aron Sebastian $^{1}$
}

\begin{abstract}
In order to adapt in changing environment, innovation is an important component in public organization. Innovation in public organization runs in two stages, the initiation stage and the implementation stage. The study examines supporting factors and barriers of innovation at the Driving Licence service agency. The paper analyzes the initiation stage and the implementation stage. In the initiation stage, the article shows the agency's decision to impement "SIM Booking Innovation" as policy to respond to the demands of the community and organization. At implementation stage, the agency implement a more technical intervention by building infrastructure such as allocating special booth and staff, For driving license extension procedure, the agency adopted the existing model. In conclusion, the article argues that the supporting factors in organization innovation consists of broad-minded and open-minded leaders, availability of facilities, and organizational support in the implementation of innovation. On the other hand, the barrier factors of innovation are the lack of special budget to support innovation program, risk aversion of subordinates and over-reliance on high-performers.
\end{abstract}

Keywords: service innovation, stages of innovation, supporting factors of innovation, barriers.

\section{PENDAHULUAN}

Dalam menghadapi era globalisasi yang penuh tantangan dan peluang, pemerintah sebagai pelayan masyarakat dituntut untuk memberikan pelayanan yang sebaik-baiknya. Pelayanan yang diberikan pada masyarakat setiap waktu selalu menuntut pelayanan publik yang berkualitas dari pemerintah (Abidin, 2006). Pelayanan yang berkualitas dan bermutu tinggi menjadi perhatian utama dari organisasi publik. Harapan untuk mendapatkan pelayanan yang terbaik mulai digantungkan kepada organisasi pemerintahan (Prianto, 2006).

Kondisi pelayanan publik di Indonesia masih jauh dari harapan masyarakat (Nugroho dkk, 2016), hal ini ditunjukkan dari banyak survey yang dilakukan oleh beberapa lembaga yang menunjukkan rapor yang buruk terkait dengan pelayanan publik

\footnotetext{
${ }^{1}$ Anggota Kepolisian Republik Indonesia yang sedang bertugas di Kepolisian Daerah Jawa Tengah
} 
di Indonesia, yaitu survey dari World Bank, International Finance Corporation (IFC), Tranparency International Indonesia (TII).

Peningkatan pelayanan publik secara optimal memerlukan berbagai inovasi. Keberadaan inovasi sangat penting untuk pelayanan publik guna memberikan terobosan terbaru yang dapat meningkatkan kualitas pelayanan (Anggraeny, 2013). Seiring dengan perkembangan administrasi publik, inovasi pelayanan publik memegang peran yang sangat penting. Inovasi pelayanan publik merupakan sebuah jawaban terhadap tuntutantuntutan masyarakat, perkembangan teknologi dan perkembangan globalisasi yang terus bergerak. Bahkan inovasi dipandang sebagai penentu dan kunci kesuksesan jangka panjang pada pasar kompetitif saat ini (Kasali, 2005).

Kepolisian RI saat ini merespon perkembangan dan tuntutan yang terjadi di masyarakat. Satuan Lalu Lintas (Satlantas) Polres Kudus yang menjadi salah satu unit pelayanan publik dibawah Kepolisian RI dituntut pula melakukan inovasi pelayanan publik. Terobosan yang dilakukan oleh Satlantas Polres Kudus dalam rangka pelayanan perpanjangan SIM adalah Inovasi "SIM BOOKING”.

Inovasi "SIM BOOKING" merupakan sebuah program yang memudahkan masyarakat yang hendak melakukan perpanjangan SIM dengan tidak mengantri. Masyarakat mendapat nomor registrasi antrian, melakukan pengambilan foto, membayar di loket pembayaran dan SIM pun jadi. Inovasi SIM BOOKING bukan hal yang mudah diciptakan. Ide-ide inovasi sering kali terlontar, namun belum dapat terwujud.

Sejumlah permasalahan terkait dengan inovasi pelayanan SIM BOOKING dalam penelitian antara lain : (1) Adanya sistem layanan yang tidak responsif, tidak efektif, stagnant dan hanya rutinitas; (2) Inovasi hanya bagus di awal, namun tidak dapat berlanjut; (3) Banyaknya tunggakan perpanjangan SIM perlu terobosan agar dapat diselesaikan; (4) Ketergantungan figur tertentu; dan (5) Kebiasaan menolak mengambil resiko (Risk Aversion). Untuk itu, Satlantas Polres Kudus berusaha untuk membuat terobosan-terobosan sebagai langkah inovasi pelayanan. Penggunaan SMS dalam pelayanan administrasi, seperti SIM BOOKING merupakan salah satu program inovasi yang dilakukan Satlantas Polres Kudus. 
Tujuan dari penulisan ini adalah:

1. Menganalisis tahapan-tahapan inovasi pelayanan perpanjangan SIM melalui "SIM BOOKING" di Satlantas Polres Kudus.

2. Menganalisis faktor pendorong dan faktor penghambat dalam inovasi pelayanan.

\section{Pengertian dan Evolusi Orientasi Administrasi Publik}

Administrasi publik terdiri dari dua kata, yaitu administrasi dan publik. Administrasi menurut Sondang P. Siagian (dalam Syafiie, 2000) diartikan sebagai keseluruhan proses pelaksanaan dari keputusan-keputusan yang telah diambil dan dilaksanakan itu pada umumnya dilakukan oleh dua orang manusia atau lebih untuk mencapai tujuan yang telah ditentukan sebelumnya. Publik yang dilekatkan pada istilah administrasi dipahami sebagai proses kepemerintahan yang selaras dengan perubahan paradigma administrasi. Syafiie, dkk (2000), arti public adalah sejumlah manusia yang punya kebersamaan berfikir, perasaan, harapan, sikap dan tindakan yang benar dan baik berdasarkan nilai-nilai norma yang mereka miliki. Dengan demikian administrasi publik diartikan sebagai sebuah proses menjalankan keputusan/kebijakan demi kepentingan negara, warga masyarakat.

Administrasi publik berevolusi secara bertahap dari perspektif klasik sampai kontemporer. Administrasi publik memiliki empat orientasi, yang masing-masing disebut dengan administrasi publik lama (old public administration), administrasi publik baru (new public administration), manajemen publik baru (new public management), dan pelayanan publik baru (new public service) (LAN, 2014). Orientasi administrasi publik dalam pemenuhan kebutuhan publik dilakukan dengan mengedepankan pendekatan keadilan dan partisipasi. Pemenuhan kebutuhan publik juga dilakukan dengan cara-cara inovatif:

\section{Gambar 1.}

\section{Evolusi Paradigma Administrasi Publik}

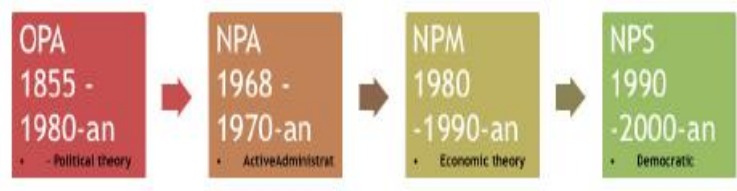

Sumber: LAN, 2014:5 


\section{Inovasi Administrasi}

Inovasi merupakan konsep yang relatif baru dalam literatur administrasi publik (public administration). Djamaludin (2012) dalam bukunya Psikologi Kepemimpinan dan Inovasi memberikan definisi inovasi sebagai "suatu proses memikirkan dan mengimplementasikan pemikiran tersebut sehingga menghasilkan hal baru berbentuk produk, jasa, proses bisnis, cara baru, kebijakan, dan lain sebagainya”. Dooley dkk (2009), menyebutkan inovasi adalah "proses membuat perubahan terhadap sesuatu yang telah mapan melalui introduksi suatu hal baru yang memberikan nilai tambah bagi konsumen". Sementara itu, Anthony (2013) memahami inovasi dalam pengertian yang lebih sederhana, yakni sebagai "sesuatu yang berbeda yang berdampak".

Inovasi sangat penting dilakukan oleh pemerintah dalam meningkatkan pelayanan publik mengingat kondisi perubahan lingkungan yang terjadi. Inovasi diharapkan dapat menanggapi kompleksitas lingkungan dan dinamisasi perubahan lingkungan terutama dalam persaingan yang ketat dan menciptakan sumber-sumber dalam keunggulan bersaing. Inovasi berasal dari kreatifitas ide-ide baru yang diterapkan secara praktis dan a ktual yang bersumber dari: (1) Pengetahuan baru (New knowledge); (2) Saran / ide konsumen (tapping the ideas of costumer); (3) Pengguna utama (lead user); (4) Desain yang memahami konsumen (emphatic design); (5) Penemuan (invention factories); dan (6) Skunkworks (memperkerjakan orang berbakat) (Havard Bussiness Essential, 2003).

Jenis inovasi dalam sektor publik dalam Handbook Inovasi Administrasi Negara (2014), yaitu: (a) Inovasi proses, (b) Inovasi metode, (c) Inovasi produk, (d) Inovasi konseptual, (e) Inovasi tekonogi, (f) Inovasi struktur organisasi, (g) Inovasi hubungan, dan (h) Inovasi pengembangan sumber daya manusia.

Proses inovasi bagi organisasi berbeda dengan proses yang terjadi secara individu. Organisasi, publik dalam mengadopsi produksi inovasi akan melalui tahapan sebagai berikut (Roger, 2003):

a) Initiation atau perintisan, di mana seluruh informasi dikumpulkan, dikonsep dan direncanakan untuk didiskusikan sebagai inovasi. Tahap perintisan terdiri dari fase agenda setting dan matching:

1. Tahapan agenda setting dilakukan proses identifikasi penetapan prioritas kebutuhan dan masalah, pencarian dalam lingkungan organisasi untuk 
menentukan tempat di mana inovasi akan diaplikasikan. Tahapan ini seringkali memakan waktu lama.

2. Tahapan matching atau penyesuaian dengan inovasi yang hendak diadopsi. Tahapan ini memastikan feasibilities atau kelayakan inovasi untuk diaplikasikan dalam organisasi

b) Implementation atau pelaksanaan, menyelesaikan permasalahan organisasi. Tahapan implementasi ini terdiri atas fase redefinisi, klarifikasi dan rutinitas.

1. Fase redefinisi (redefining) di mana seluruh inovasi yang diadopsi mulai kehilangan karakter asingnya sehingga lebih dekat dalam mengakomodasi kebutuhan organisasi.

2. Fase klarifikasi (clarifying) terjadi ketika inovasi sudah digunakan secara meluas dalam organisasi dan mempengaruhi seluruh elemen organisasi dalam keseharian kerjanya.

3. Fase rutinitas (routinizing) adalah fase di mana inovasi sudah dianggap sebagai bagian dari organisasi. Inovasi tidak lagi mencirikan sebuah produk baru atau cara baru karena telah menjadi bagian rutin penyelenggaraan organisasi.

\section{Faktor - Faktor Penunjang dan Penghambat Inovasi}

Kemampuan inovasi suatu lembaga menurut Terziovski (dalam Prasmi, 2015) ditentukan oleh sejumlah faktor yang disebutnya sebagai dimensi kemampuan inovasi yang meliputi: visi dan strategi, perekatan dasar kompetensi, penguatan informasi dan kecerdasan organisasi, orientasi pasar dan pelanggan, kreativitas dan manajemen gagasan, sistem dan struktur organisasi, dan manajemen teknologi.

Faktor penunjang inovasi lainnya menurut Everett M. Rogers (2003) dapat ditunjang oleh beberapa faktor pendukung, antara lain:

(a) Adanya keinginan untuk merubah diri, dari tidak bisa menjadi bisa dan dari tidak tahu menjadi tahu

(b) Adanya kebebasan berekspresi

(c) Adanya pembimbing yang berwawasan luas dan kreatif

(d) Tersedianya sarana dan prasarana

(e) Kondisi lingkungan harmonis 
Inovasi tidak terjadi secara mulus atau tanpa resistensi. Albury (dalam Suwarno, 2014) mengidentifikasikan 7 (tujuh) jenis hambatan dalam inovasi, yaitu:

(1) Tidak ada penghargaan / intensif

(2) Ketidakmampuan menghadapi resiko dan perubahan

(3) Anggaran jangka pendek dan perencanaan

(4) Tekanan hambatan administratif

(5) Budaya "Risk Aversion"

(6) Keengganan menutup program yang gagal.

(7) Teknologi ada, terhambat budaya \& penataan organisasi.

(8) Ketergantungan berlebihan pada high performer

\section{Pelayanan Satlantas Polres Dalam Perpanjangan SIM}

Satlantas merupakan unsur pelaksana yang menyelenggarakan tugas kepolisian mencakup pengaturan, penjagaan, pengawalan dan patroli (Turjawali), pendidikan masyarakat dan rekayasa lalu lintas, registrasi dan identifikasi pengemudi atau kendaraan bermotor, penyidikan kecelakaan lalu lintas dan penegakan hukum dalam bidang lalu lintas guna keamanan, ketertiban dan kelancaran lalu lintas. Peraturan Kepala Kepolisian Negara Republik Indonesia Nomor 23 Tahun 2010 tentang Susunan Organisasi dan Tata Kerja Pada Tingkat Kepolisian Resort dan Kepolisian Sektor, pasal 1 angka (20) disebutkan bahwa, Satuan Lalu Lintas yang selanjutnya disingkat Satlantas adalah unsur pelaksana tugas pokok fungsi lalu lintas pada tingkat Polres yang berada di bawah Kapolres.

Peraturan Kapolri nomor 9 tahun 2012 tentang Surat Izin Mengemudi (SIM) menyebutkan bahwa:

"Surat Izin Mengemudi yang selanjutnya disingkat SIM adalah tanda bukti legitimasi kompe-tensi, alat kontrol, dan data forensik kepolisian bagi seseorang yang telah lulus uji pengetahuan, kemampuan, dan keterampilan untuk mengemu-dikan Ranmor di jalan sesuai dengan persyaratan yang ditentukan berdasarkan Undang-Undang Lalu Lintas dan Angkutan Jalan.”

Dengan demikian, secara singkat, fungsi SIM dapat dikatakan sebagai: (a) legitimasi kompetensi pengemudi; (b) identitas pengemudi; (c) kontrol kompetensi Pengemudi; (d) forensik kepolisian; dan (e) pelayanan prima. 
Program pelayanan perpanjangan SIM melalui SIM BOOKING dipenuhi melalui persyaratan dan pelayanan sebagai berikut:

(a) KTP Pemohon

(b) Pemohon mengirim pesan dengan format secara berurutan nama, alamat, jenis SIM, dan nomor SIM

(c) Pesan diterima petugas, kemudian, petugas mengirim balasan pesan konfirmasi

(d) Pemohon datang ke Mapolres setempat dengan membawa persyaratan

(e) Setelah persyaratan lengkap, tidak perlu antri, warga menunjukan pesan konfirmasi dengan menyerahkan persyaratan lengkap

(f) Setelah pemeriksaan berkas, pemohon akan dipanggil untuk foto dan SIM Perpanjangan jadi

\section{METODE PENELITIAN}

Penelitian ini merupakan penelitian deskriptif dengan pendekatan kualitatif. Ruang lingkup penelitian ini adalah tahapan-tahapan inovasi pelayanan beserta faktor penunjang dan penghambatnya. Situs penelitian adalah Satlantas Polres Kudus. Teknik pengumpulan data menggunakan teknik wawancara, observasi dan dokumentasi. Adapun teknik analisis data menggunakan analisis model interaktif dan uji keabsahan data menggunakan uji triangulasi sumber.

\section{HASIL DAN PEMBAHASAN}

\section{Tahapan-Tahapan Pelayanan Perpanjangan SIM melalui "SIM BOOKING"}

Inovasi dalam administrasi publik dimaknai sebagai proses memikirkan dan mengimplementasikan suatu kebijakan oleh penyelenggara kepentingan publik untuk memenuhi kepentingan publik yang memiliki unsur kebaharuan serta kemanfaatan. Inovasi sangat penting dilakukan oleh pemerintah dan organisasi publik dalam meningkatkan pelayanan publik mengingat kondisi perubahan lingkungan yang terjadi. Inovasi merupakan upaya memper-tahankan keberadaan organisasi dalam lingkungan. Adanya inovasi organisasi ini diharapkan dapat menanggapi kompleksitas lingkungan dan dinamisasi perubahan lingkungan.

Proses inovasi bagi organisasi berbeda dengan proses yang terjadi secara individu. Sebagai sebuah organisasi, sektor publik dalam mengadopsi produksi inovasi akan 
melalui tahapan initiation atau perintisan dan implementation atau pelaksanaan (Rogers, 2003). Tahapan initiation atau perintisan menurut Everett M. Rogers (2003) terdiri dari fase agenda setting dan fase matching (penyesuaian), sedangkan tahapan implementation atau pelaksanaan terdiri dari fase redefining (redefinisi), fase clarifying (klarifikasi) dan fase routinizing (rutinitas).

Tahap inisiation yang terdiri dari tahap agenda setting dan tahap matching, terlihat bahwa inovasi mulai diidentifikasi sebagai kebutuhan untuk menyelesaikan masalah antrian yang lama hingga disesuaikan dalam agenda internal organisasi Penyesuaian-penyesuaian terhadap berbagai kriteria pada tahap matching sangat diperlukan. Penyesuaian berdasarkan kriteria dalam administrasi publik (Sawicki dkk, 1986) dapat didasarkan pada kriteria keuangan (financial posibilities), kriteria administrasi (administratif operability), kemampuan teknis (teachnical feasabilities), dan kriteria dukungan politis (political viability). Dalam penelitian ini, inovasi SIM Booking telah memenuhi kriteria-kriteria yang ditetapkan secara keseluruhan sehingga pada tahap pelaksanaan nanti dapat sejalan dengan tujuan yang diharapkan.

Tahapan pelaksanaan yang diamati melalui fase redefinisi (redefining), fase klarifikasi (clarifying) dan fase rutinitas (routinizing). Berdasarkan serangkaian tahapan pelaksanaan yang diamati maka hasil penelitian menunjukkan bahwa pada fase redifinisi, adanya staf khusus dan loket khusus beserta petugas yang telah dilatih secara khusus untuk mengawali pelaksanaan inovasi SIM BOOKING. Inovasi tidak secara keseluruhan menggantikan mekanisme pengajuan lama, tetapi diadaptasikan secara bertahap kepada lingkungan. Dalam inovasi SIM BOOKING menunjukkan terjadi proses perubahan pelayanan terhadap penerbitan SIM. Sebagian proses tidak lagi melayani secara konvensional dengan antrian banyak pemohon. Staf mulai memiliki data pemohon yang sudah secara otomatis masuk karena adanya SMS untuk booking pengajuan SIM.

Fase klarifikasi membutuhkan waktu karena mempengaruhi seluruh elemen organisasi dan dilakukan sosialisai berupa pemahaman kepada internal organisasi dan masyarakat terhadap SIM BOOKING. Klarifikasi juga berguna untuk menyamakan persepsi tentang fungsi dan tujuan inovasi SIM BOOKING. 
Fase rutinitas merupakan fase di mana SIM BOOKING telah menjadi suatu pelayanan reguler atau keseharian dan menjadi upaya perbaikan pelayanan bagi Satlantas Polres Kudus. Secara sederhana, proses inovasi dapat dilihat dalam tabel berikut:

Tabel 1.

Tahapan-Tahapan Inovasi SIM Booking Satlantas Polres Kudus

\begin{tabular}{|c|c|c|c|c|c|}
\hline \multirow[t]{2}{*}{ Thn } & \multicolumn{2}{|c|}{ INISIATION } & \multicolumn{3}{|c|}{ IMPLEMENTATION } \\
\hline & Agenda Setting & Matching & Redifining & Clarifiying & Routinizing \\
\hline 2014 & $\begin{array}{l}\text { Inovasi } \\
\text { pelayanan } \\
\text { diperlukan } \\
\text { menjawab } \\
\text { persoalan } \\
\text { organisasi. } \\
\text { Pimpinan } \\
\text { memasukkan } \\
\text { "Inovasi SIM } \\
\text { Booking" guna } \\
\text { menanggapi } \\
\text { tuntutan } \\
\text { masyarakat dan } \\
\text { tuntutan } \\
\text { organisasi. }\end{array}$ & & & & \\
\hline 2015 & & $\begin{array}{l}\text { Penyesuaian } \\
\text { inovasi SIM } \\
\text { Booking } \\
\text { berdasar } \\
\text { kriteria } \\
\text { keuangan, } \\
\text { kriteria } \\
\text { administrasi } \\
\text { kemampuan } \\
\text { teknis dan } \\
\text { kriteria } \\
\text { dukungan } \\
\text { politis. }\end{array}$ & $\begin{array}{l}\text { Penempatan } \\
\text { loket khusus } \\
\text { dan staf } \\
\text { khusus yang } \\
\text { di trainning } \\
\text { dimana } \\
\text { inovasi } \\
\text { mengalami } \\
\text { adopsi dan } \\
\text { mulai berbaur } \\
\text { dengan } \\
\text { mekanisme } \\
\text { pengajuan } \\
\text { SIM }\end{array}$ & & \\
\hline 2016 & & & & $\begin{array}{l}\text { Sosialisasi } \\
\text { dilakukan } \\
\text { oleh } \\
\text { Satlantas } \\
\text { Polres } \\
\text { Kudus, } \\
\text { internal dan }\end{array}$ & \\
\hline
\end{tabular}




\begin{tabular}{|c|c|c|c|c|c|}
\hline \multirow[t]{2}{*}{ Thn } & \multicolumn{2}{|c|}{ INISIATION } & \multicolumn{3}{|c|}{ IMPLEMENTATION } \\
\hline & Agenda Setting & Matching & Redifining & Clarifiying & Routinizing \\
\hline & & & & $\begin{array}{l}\text { eksternal } \\
\text { untuk } \\
\text { klasrifikasi }\end{array}$ & \\
\hline 2017 & & & & & $\begin{array}{l}\text { SIM } \\
\text { Booking } \\
\text { menjadi } \\
\text { suatu } \\
\text { pelayanan } \\
\text { reguler atau } \\
\text { keseharian. }\end{array}$ \\
\hline
\end{tabular}

Sumber: Olahan peneliti, 2017.

\section{Faktor-Faktor pendorong dan Penghambat Inovasi "SIM BOOKING" di Satlantas}

\section{Polres Kudus}

Kemampuan inovasi suatu lembaga menurut Terziovski (2007) ditentukan oleh sejumlah faktor, antara lain meliputi: visi dan strategi, perekatan dasar kompetensi, penguatan informasi dan kecerdasan organisasi, orientasi pasar dan pelanggan, kreativitas dan manajemen gagasan, sistem dan struktur organisasi, dan manajemen teknologi. Sementara menurut Kurniawati (2014) terdapat 15 faktor yang menentukan keberhasilan inovasi organisasi, antara lain: (1) iklim dan budaya kreatif; (2) individuindividu yang tidak konvensional; (3) pekerja yang memenuhi syarat dan bekerja atas perusahaan; (4) ukuran organisasi, sistem insentif dan sentralisasi kekuasaan; (5) intensitas riset dan pengembangan; (6) fleksibilitas organisasi, (7) pengumpulan informasi eksternal, (8) strategi, teknologi, manusia/budaya struktur, manajerial dan lingkungan, (9) identitas, proses kerja, penilaian situasi, akuntabilitas kolektif, dan (10) gaya kepemimpinan yang bernilai kewirausahaan anggota, (11) fokus pada pelanggan dan pasar, (12) jaringan informasi internal dan eksternal, (13) manajemen pengetahuan dan pengembangan, dan (14) perbaikan terus menerus, serta (15) adopsi teknologi.

Hasil penelitian menunjukkan bahwa faktor pendorong pelaksanaan inovasi SIM BOOKING di Satlantas Polres Kudus adalah motivasi pimpinan dan dukungan organisasi. Pimpinan menjadi motivator dan inspirasi bawahan dalam berinovasi. Pimpinan juga berpikiran terbuka dan selalu memberi dukungan terhadap ide atau 
gagasan inovasi. Faktor dukungan dari organisasi membuat inovasi SIM BOOKING dapat dijadikan sebagai rutinitas pelayanan.

Inovasi tidak terjadi secara mulus atau tanpa resistensi. Banyak dari kasus inovasi di antaranya justru terkendala oleh berbagai faktor. Albury (dalam Suwarno, 2008) mengidentifikasikan 7 (tujuh) jenis hambatan dalam inovasi. Ketujuh jenis hambatan antara lain: anggaran jangka pendek dan perencanaan, budaya "Risk Aversion", ketergantungan berlebihan pada high performer.

Hasil penelitian menunjukkan bahwa ketiga faktor tersebut terdapat dalam pelaksanaan inovasi SIM BOOKING di Satlantas Polres Kudus. Ketidaktersediaan anggaran khusus untuk kegiatan inovasi di Satlantas Polres Kudus menunjukkan bahwa anggaran tidak secara khusus disediakan untuk berinovasi. Peran pemimpin yang dominan untuk dapat menjalankan inovasi menunjukkan ketergantungan berlebihan pada high performer. Sementara bawahan bersikap pasif, bahkan tidak pernah memberikan ide atau gagasan berinovasi menunjukkan adanya budaya "Risk Aversion" atau menghindari resiko. Bawahan cenderung tidak ingin beresiko dan menyerahkan semua resiko pada pimpinan. Semua tanggung jawab inovasi berada pada pimpinan organisasi. Faktor pendorong dan faktor penghambat dalam pelaksanaan inovasi SIM BOOKING Satlantas Polres Kudus dapat dilihat dalam Tabel berikut:

Tabel 2.

Faktor Pendorong dan Faktor Penghambat Inovasi SIM Booking

\begin{tabular}{|l|l|}
\hline \multicolumn{1}{|c|}{ Faktor Pendorong } & \multicolumn{1}{|c|}{ Faktor Penghambat } \\
\hline $\begin{array}{l}\text { Pimpinan yang berwawasan luas dan } \\
\text { berpikiran terbuka }\end{array}$ & $\begin{array}{l}\text { Tidak tersedianya anggaran khusus } \\
\text { untuk inovasi. }\end{array}$ \\
\hline $\begin{array}{l}\text { Ketersediaan sarana dan prasarana yang } \\
\text { memadai. }\end{array}$ & $\begin{array}{l}\text { Budaya menghindari resiko (risk } \\
\text { aversion) dari bawahan. }\end{array}$ \\
\hline $\begin{array}{l}\text { Dukungan organisasi yang } \\
\text { mempermudah pelaksanaan inovasi. }\end{array}$ & $\begin{array}{l}\text { Ketergantungan berlebih pada atasan } \\
\text { (high performer) }\end{array}$ \\
\hline
\end{tabular}

Sumber: Olahan peneliti, 2017. 


\section{PENUTUP}

\section{Kesimpulan}

Berdasarkan hasil penelitian, disimpulkan sebagai berikut:

1. Tahapan-tahapan inovasi pelayanan perpanjangan SIM melalui SIM BOOKING di Satuan Lalu Lintas (Satlantas) Polres Kudus terdiri dari tahapan inisiasi (initiation) dan tahapan pelaksanaan (implementation). Meskipun tahapan telah dilalui, namun temuan penelitian menunjukkan bahwa Inovasi SIM perpanjangan melalui SIM BOOKING di Satlantas Polres Kudus mengalami keluasan cakupan sehingga dalam pelaksanaan tidak semua tujuan dan mekanisme inovasi SIM BOOKING dapat dipahami. Inovasi berjalan sangat lambat dan kurang berhasil.

2. Faktor penunjang dan faktor penghambat dalam inovasi pelayanan adalah :

a. Faktor penunjang dalam inovasi pelayanan adalah pimpinan yang berwawasan luas dan berpikiran terbuka dan dukungan organisasi yang permudah pelaksanaan inovasi.

b. Faktor penghambat dalam inovasi pelayanan adalah tidak tersedianya anggaran khusus untuk inovasi, budaya menghindari resiko (risk aversion) dari bawahan, ketergantungan berlebih pada atasan (high performer) dan ketersediaan sarana serta prasarana yang kurang memadai.

\section{Saran}

1. Inovasi pelayanan SIM BOOKING melalui aplikasi android menjadi sesuatu yang patut dikembangkan.

2. Ketergantungan figur high performer perlu dikurangi dengan penumbuhan kepercayaan diri kepada bawahan oleh pimpinan.

3. Pimpinan memberikan dukungan melalui penghargaan bagi anggota yang memiliki ide inovasi untuk mengurangi budaya "Risk Aversion".

4. Mengajukan dana inovasi dalam bentuk dana pengembangan organisasi ataupun dana riset dan pengembangan organisasi.

5. Mengaktifkan Kotak Saran, baik secara konvensional maupun On Line di bagian pelayanan SIM untuk menjaring ide atau gagasan berinovasi dari masyarakat

6. Menjalin kerjasama dengan Perguruan Tinggi untuk berdiskusi dan mendapat masukkan tentang inovasi pelayanan. 


\section{DAFTAR PUSTAKA}

Abidin, Said Zainal. 2006. Kebijakan Publik. Jakarta: Suara Bebas.

Anggraeny, Cindy. 2013. Inovasi Pelayanan Kesehatan Dalam Meningkatkan Kualitas Pelayanan di Puskesmas Jagir Kota Surabaya. Unair Surabaya: Jurnal Kebijakan dan Manajemen Publik, Vol. 1 No. 1, hlm 85-93.

Anthony, Scott. D. 2013. The Little Black Book of Innovation: Bagaimana Inovasi Bekerja, Bagaimana Kita Melakukannya. Jakarta: Elex Media Computindo.

Dooley, Lawrence and David O’Sullivan. 2009. Applying Innovation. Thousand Oaks, CA: Sage.

Djamaludin, Ancok. 2012. Psikologi Kepemimpinan \& Inovasi. Jakarta: Erlangga.

Havard Bussiness Essential. 2003. Managing Creativity and Innovation. Havard Bussiness Press, Boston - USA.

Kasali, Renald. 2005. Change. Jakarta: Gramedia Pustaka Utama.

Nugroho, S.A., Kismartini, dan Purnaweni, H. 2016. Reformasi Administrasi Pelayanan Publik (Studi Pelayanan Administrasi Terpadu Kecamatan Jawa Tengah). Gema Publica-Jurnal Manajemen dan Kebijakan Publik, hlm 13-27.

Prasmi, M. Rasyid dan Ulung Pribadi. 2015. Inovasi Kelembagaan Unit Pelayanan teknis Dinas Balai Rehabilitasi Terpadu Penyandang Disabilitas di Dinas Sosial Daerah Istimewa Yogyakarta. Jurnal Ilmu Pemerintahan \& Kebijakan Publik, Vol.2 No.3, hlm 625-642.

Prianto, Agus. 2006. Menakar Kualitas Pelayanan Publik. Malang: In-Trans.

Rogers, Everett M. 2003. Diffusion of Innovations, Fifth Edition. New York: Free Press.

Sawicki, David S., and Carl V. Patton. 1986. Basic Methods of Policy Analysis and Planning. New Jersey: Prentice-Hall.

Suwarno, Yogi. 2008. Inovasi di Sector Publik. Jakarta: STIA-LAN Press.

Syafiie, Inu Kencana. 2000. Ilmu Administrasi Publik. Jakarta: Penerbit Rineka Cipta.

Terziovski, M. 2007. Building Innovation Capability in Organizations: An International Cross-Case Perspective. London: Imperial College Press.

Tim Pusat Inovasi Tata Pemerintahan. 2014. Handbook Inovasi Administrasi Negara. Jakarta: LAN. 